\title{
Introduction: Beyond Implicit Political Dichotomies and Linear Models of Change in China
}

\section{Vivienne Shue and Patricia M. Thornton}

How, practically speaking, amid all the economic and political turbulence of the twenty-first century, is the Chinese polity - as immense and as formidably fissured as it has now become - being governed? And what are the soundest approaches students and scholars can now choose to employ in the quest for fuller answers to all the many dimensions of this puzzling question? These are the unsolved problems of understanding that preoccupy us in this volume.

The essays to come have their origins in a conference convened at Oxford University in the spring of $2012,{ }^{1}$ but each one has been revised in light of more recent political developments. As late as 2011, as we were sending out the invitations, we still thought of the research task we and our conference participants would face as essentially exploratory - one of mapping an expanding universe of changing political practices widely recognized to be emerging in China. Our initial charge to our conference contributors was simply that they consider the complex of processes entailed in "governing and being governed" in the contemporary Chinese context, and utilize their own most recent research investigations and data to illuminate some dimension of how governance is currently being approached and realized. This investigative and empirical orientation was not chosen with a view to building a comprehensive characterization of the deep nature or final trajectory of the governing system as a whole, but instead intended to sample what we suspected would be a broad and unevenly choreographed repertoire of governing practices. The open-endedness of that initial approach has, we still believe, encouraged our authors to feature in their essays here some of those governing

${ }^{1}$ The conference on "Power in the Making: Governing and Being Governed in Contemporary China" was organized by the University of Oxford's Contemporary China Studies Programme, a ten-year research development initiative generously funded by the Leverhulme Trust. We are grateful to all those who attended and took part in that meeting for their many insights, and wish to record our thanks also to Christopher Kutarna who served as rapporteur. 
practices that have previously been relegated to the margins of view. And it has allowed us all to highlight some of the fascinating, occasionally ironic, internal inconsistencies and jarring anomalies of a decidedly mixed system that is still in the making.

As of this writing in 2016, however, we have concluded that it has become possible, indeed necessary, to press our modest initial conceptual agenda still further forward. On the basis of what we have learned from the diverse studies collected here, as well as from other recent work in the fields of Chinese and comparative political and social studies, we wish to suggest a refreshed framework for approaching the study of governance in China, and what we hope may serve as a progressive new orientation for future research. But before presuming to point to any new way forward, it is necessary for us to provide an overview and reconsideration of just where our field of study has lately been.

In the Anglophone scholarship on Chinese society and politics over recent decades, with its emphasis on the Chinese Communist Party (CCP)-led effort at "system reform," some analysts have chosen to highlight signs of "progress" in the direction of a more liberal, open, and popularly responsive future for the Chinese polity. Others have dwelt instead on system reform failures and the many remaining "obstacles" to achieving a genuine transition to democracy. As we hope this volume may help serve to illustrate, these undeniably complex and seemingly contradictory trends that scholars based in the West have observed and recorded have often been conceptualized and debated against the backdrop of overly drawn distinctions between democratic and nondemocratic regime types. And they have tended to concentrate too narrowly on governing institutions as opposed to governing practices. They have failed, thereby, to capture adequately the wide assortment of idioms and the interlaced array of channels through which political evolution may proceed.

\section{From Transition Studies to Authoritarian Resilience}

A quarter of a century ago the entire world, much taken by surprise, witnessed the spectacle of serial socialist state breakdowns that the esteemed American political scientist Ken Jowitt was prompt to label the "Leninist extinction." Amazed and elated, many observers in the West then began thinking in terms of world history's cartwheeling smartly into a brand new "post-communist" era - an era of comprehensive transition toward democratic systems of governance in countries all

${ }^{2}$ Jowitt, New World Disorder: The Leninist Extinction. 
around the globe, including China. Hopes were high then, in the West, for a rather speedy Chinese transition to democracy, through one scenario or another. As Andrew Nathan was retrospectively to acknowledge, in the wake of the 1989 Tiananmen crisis "many China specialists and democracy theorists - myself among them - expected the regime to fall to democratization's 'third wave.' [But] instead, the regime has reconsolidated itself." ${ }^{3}$ Recognizing then that the "causes of its resilience are complex," Nathan nonetheless went on to single out the degree and nature of the Chinese regime's institutionalization - which he defined in terms of the "adaptability, complexity, autonomy, and coherence of state organizations" - as playing the determinative role in ensuring its suppleness and survival through the Deng Xiaoping era, and beyond.

Nathan's 2003 observations about Chinese party-state institutions were in keeping with the findings of a growing number of other studies within the broader field of comparative governance. Scholars of politics in other contemporary settings had by then begun documenting the dynamics of an "undemocratic undertow" detected in the wake of democracy's "third wave." Certain authoritarian regimes were found to be stubbornly "resilient" or "durable" in face both of internal and external challenges. As Snyder was to note, the final ebbing of the third wave saw entrenched totalitarian and post-totalitarian party-states maintain their grip on power not only in the People's Republic of China (PRC), but also in North Korea, Cuba, Laos, and Vietnam; autocratic monarchies persisted in Saudi Arabia, Morocco, and Jordan; dictatorships, theocracies, ethnocracies, and military regimes continued to survive across the globe. ${ }^{4}$ Thus, by the dawn of the twenty-first century "transitology," and what Carothers had famously called the "transition paradigm," $"$ were already showing signs of having exhausted their usefulness - particularly as "hybrid" political regimes (partly authoritarian and partly democratic) were perceived to be proliferating.

Without missing a beat then, a new generation of Western scholarship began probing the characteristics and dynamics of these more obstinate authoritarian regimes, mapping out broader taxonomies to include newly recognized categories as well, such as "competitive autocracies" and "defective democracies." 6 In contrast to an earlier scholarly literature on non-democracies, which had posited that it was the defective design of state institutions that would ultimately undermine the hold of elites on

\footnotetext{
3 Nathan, "Authoritarian Resilience," 6.

4 Snyder, "Beyond Electoral Authoritarianism."

${ }^{5}$ Carothers, "The End of the Transitions Paradigm."

${ }^{6}$ Levitsky and Way, Competitive Authoritarianism; Merkel, "Embedded and Defective Democracies"; Bogaards, "How to Classify Hybrid Regimes?"
} 
power in authoritarian regimes, ${ }^{7}$ a growing number of studies in the emerging field of "comparative authoritarianism" argued instead that autocratic elites were becoming adept at creating modern political institutions that would consolidate their hold on power and, in so doing, successfully foster more durable forms of authoritarian rule. Increasingly, this newer scholarship regards the existence of liberalizing and democratic institutions, such as political parties and legislatures in autocracies, no longer as mere fig leaves thinly disguising the exercise of coercive and repressive power. Instead, it links the structures and functions of such institutions to popular quiescence, social stability, and regime survival, significantly altering our understanding of how authoritarianism actually works, on the inside. ${ }^{8}$ This rapidly developing literature not only posits that institutions and organizations "matter" in non-democracies, it employs functionalist models ${ }^{9}$ to demonstrate that political institutions are in fact the critical causal variables in the survival of authoritarian regimes.

This so-called "institutional turn" in the comparative study of authoritarianism ${ }^{10}$ has already had a significant impact on scholarship in the China field. Nathan's influential article coining the term "authoritarian resilience" in reference to the post-Mao party-state argued that sustained popular support for the government was owed in large part to the skillful deployment of a variety of "input institutions" that worked to siphon off popular discontent without destabilizing the system as a whole. ${ }^{11}$ Dali Yang's Remaking the Chinese Leviathan argued, in a similar vein, that since the late 1980s the post-Deng leadership had responded to periodic crises by rebuilding the "institutional sinews of the central state," undertaking costly but necessary administrative restructuring which, in turn, improved governance. ${ }^{12}$ Several recent studies point to the functional adaptability of the CCP itself in ensuring system survival, highlighting the regularization and upgrading of internal party procedures governing cadre appointments, promotions, and management, ${ }^{13}$ including leadership training and education. ${ }^{14}$ The considerable malleability of

${ }^{7}$ Bunce, Subversive Institutions.

${ }^{8}$ Key works in this vein include Brownlee's Authoritarianism in an Age of Democratization; Gandhi's Political Institutions under Dictatorship; Levitsky and Way's Competitive Authoritarianism; Magaloni's Voting for Autocracy; and Slater's Ordering Power. For a fine review of some of this literature, see Art, "What Do We Know about Authoritarianism after Ten Years?"

${ }^{9}$ Jones, "Seeing like an Autocrat," 26; Blaydes, Elections and Distributive Politics in Mubarak's Egypt, 2-3.

10 Pepinsky, "The Institutional Turn in Comparative Authoritarianism."

${ }^{11}$ Nathan, "Authoritarian Resilience," 6.12 Yang, Remaking the Chinese Leviathan.

${ }^{13}$ Landry, Decentralized Authoritarianism; Edin, "State Capacity and Local Agent Control."

${ }^{14}$ Tsai and Dean, “The CCP's Learning System"; Pieke, The Good Communist. 
party ideology, further, is cited by some as an important contributor to its longevity; ${ }^{15}$ while others put more emphasis on the important role of informal institutions in ensuring party-state survival. Kellee Tsai, for example, singles out the role of informal coping strategies deployed by actors working in local settings to expand the range of allowable activities and responses within preexisting institutions. These "informal adaptive institutions" in her view, which range from the quasi-legalization of private enterprise to the calculated expansion of the party's ranks to embrace private entrepreneurs, and even the amendment of the state constitution to sanction private sector development, all worked, without ever subverting the prevailing political system, to adjust and enlarge existing institutions of state power and address new challenges. ${ }^{16}$ Likewise, in her work on public goods provision in rural China, Lily Tsai highlights the roles of "informal institutions of accountability" in bolstering the resilience of the system. Looking at local solidary groups chiefly village temple associations whose activities foster a sense of shared moral obligation between local officials and rural residents - she documents how extra-bureaucratic, extra-legal forms of community accountability can supplement the perceived legitimacy, and increase the responsiveness, of a multi-tiered governing apparatus otherwise acutely prone to remoteness and rigidity. ${ }^{17}$

Even as these new studies helped to deepen our understanding of the workings of "authoritarian resilience," however, they also revealed a wide and partly conflicting range of opinions coexisting within the Chinese elite regarding the ultimate rationales and longer-term goals of political reform, as well as its optimal timing and sequencing. ${ }^{18}$ These internal debates were protracted, and frequently fierce. With so much intense elite contestation about how to reform and reinvigorate the party-state system going on inside China itself, a few unflinching scholars, like Jean-Pierre Cabestan, were moved to question the necessary inevitability of Westernstyle liberalization and raise instead the possibility "that China will once again innovate and manage its retreat from communism through a movement towards a softer but stabilized authoritarianism." Cabestan envisioned evolution into a system "that is consultative yet also elitist and corporatist"; one "equipped with a certain legal modernity but not with the rule of law, and only partly institutionalized." ${ }^{19}$ Most scholars in the

${ }^{15}$ Shambaugh, China's Communist Party: Atrophy and Adaptation; Holbig, Ideological Reform and Regime Legitimacy; Dickson, Wealth into Power.

16 Tsai, "Adaptive Informal Institutions." ${ }^{17}$ Tsai, Accountability without Democracy.

${ }^{18}$ See, e.g., Dittmer, "Three Visions"; Heberer and Schubert, "Political Reform and Regime Legitimacy."

19 Cabestan, "Is China Moving?," 21. 
field, however, like John Lewis and Litai Xue, remained inclined to rule out any satisfactory middle way or "soft authoritarian" solution in the longer run. Either simply overlooking or thoroughly discounting many of the actual reforms that were then ongoing within the party, as well as the lively internal contestation over the very meaning of "political system reform" itself, they concluded instead that "one party rule in China" is still just "living on borrowed time." ${ }^{20}$ A clear choice against authoritarianism and in favor of democracy would still, one day, have to be made, they argued, on the grounds that, "More challenging forms of political competition will sooner or later emerge as divergent interests further fracture party unity and as the disfranchised and disconnected elements of society seek political justice and coalesce into a viable opposition."21

Much of the most sophisticated scholarship in the China studies field of late has, thus, still left us juggling uncomfortably with an antinomy. The mounting evidence does seem to show that, over the years, the CCP has, on the one hand, learned how to rule more subtly and astutely than before. And yet, many have predicted that the "reformauthoritarian" learning curve of the party-state will not extend indefinitely, particularly in light of continuously rising levels of social protest and rampantly festering official corruption. As Andrew Nathan once again, embracing the "performance legitimacy" approach to analyzing the party-state's longevity, has more recently observed, the presumed durability of China's authoritarian pact remains contingent upon the party's ability to deliver consistently high rates of economic growth and deflect internal challenges. But, in order to do so, the "regime must perform constantly like a team of acrobats on a high wire, staving off all crises while keeping its act flawlessly together." Under such tenuous conditions, rather than as a display of "resilience," he suggests that the state of affairs in China now might better be characterized as one of "authoritarian impermanence." 22 Pei Minxin and Cheng Li have likewise sounded speculative early warning bells on the continued longevity of China's ostensibly resilient authoritarian regime, citing a decline in the CCP's capacity to coopt new elites, the crystallization of increasingly activist oppositional forces within Chinese society, and persistent schisms within the upper echelons of the party. ${ }^{23}$ Writing on the eve of the world

${ }^{20}$ Dickson, Red Capitalists; Cabestan, "Is China Moving?"; Yang, Remaking the Chinese Leviathan; Schubert, "Reforming Authoritarianism"; and Tsai, Capitalism without Democracy.

${ }^{21}$ Lewis and Xue, "Social Change and Political Reform," 942.

${ }^{22}$ Nathan, "Authoritarian Impermanence."

${ }^{23} \mathrm{Li}$, "The End of the CCP's Resilient Authoritarianism?"; Pei, "Is CCP Rule Fragile or Resilient?" 
financial crisis and drawing attention to what some continued to treat as a puzzling contrast between the PRC's remarkably positive economic performance and its autocratic political vulnerabilities, Susan Shirk similarly went so far as to tag China as the "fragile superpower."24

Among prominent scholars based within the PRC itself, Sun Liping has drawn attention to the ways in which the "phantom of instability" (不稳定 幻像) continues to drive a vicious circle of repression that he predicts will likely produce large-scale social unrest in the future. ${ }^{25} \mathrm{Yu}$ Jianrong has criticized the $\mathrm{Hu}$-Wen government's pursuit of a "socialist harmonious society” as having generated instead a form of “rigid stability” (刚性稳定) that may easily be broken, because it is based on the coercive power of the state to suppress social interests. The only way to reduce the mounting pressure on the system as a whole, Yu argues, is through a combination of "fundamental institutional change and institution-building" and construction of "a robustly institutionalized mechanism for the protection of rights." ${ }^{26}$ Sooner or later - or so the evidence seems to indicate to many experts, both in and outside of China, "authoritarian resilience" must somehow be supplanted by genuinely liberal, more democratic, political institutions to avert the potential future crisis of state collapse.

\section{The Limits of the Authoritarian Resilience Paradigm}

Thus, at its core, notwithstanding Carothers' hasty proclamation of the end of transitology and the "transition paradigm," this newer scholarly literature on comparative authoritarianism continues to be driven either explicitly or implicitly - by a conspicuous intellectual yearning to explain the incomplete, partial, and failed "third wave" of democratization. As Howard and Walters point out in a recent critique, the continued reliance upon " $[\mathrm{t}] \mathrm{erms}$ such as 'authoritarian persistence' and 'authoritarian resilience' ... imply that authoritarianism is somehow unnatural or unsustainable under normal circumstances, thus unintentionally bringing back some of the assumptions of 'transitology' that were supposedly rejected" by the initial champions of the concept. The failure of political scientists to predict first the Soviet collapse in the aftermath of the 1989 Eastern European revolutions, and then the cascading effects of social mobilization during the 2011 Arab Spring, they reason, is the result of analysts' having overemphasized in their models "the prospects for or barriers to democratic reform," thus

${ }^{24}$ Shirk, China: Fragile Superpower. ${ }^{25}$ Sun Liping, "The 'Phantom of Instability'."

${ }^{26}$ Yu Jianrong, "From Rigid Stability to Resilient Stability"; Yu Jianrong, "The Present Predicament of Stability Maintenance," 6. 
limiting "the purview of what political developments are seen as relevant and important objects of study." 27

Sensing, as an abiding imperative, a need to explain the persistent nontransition of stable autocracies and probe the reasons for the incomplete transition of a range of functional hybrid political regimes then, contemporary scholars of comparative authoritarianism have crafted painstaking, and undoubtedly insightful, accounts that center on the institutions formal, informal, and adaptive - upon which non-democracies rely in consolidating and perpetuating their rule. In this work, however, the precise connection between particular institutions and overall regime resilience remains, as Karen Orren and Steven Skowronek have observed, still more often presumed than conclusively demonstrated. As they see it, what the neo-institutionalist turn in political science has produced, in large part due to its undergirding assumptions about how institutions operate within political systems, is "an increasingly elaborate iconography of order." Whether institutions are taken to be the crystallization of a political culture's fundamental value orientations, or as the "rules of the game" that shape behavior within a political order, or as the structures and procedures that determine the strategic context within which individuals calculate their self-interest, Orren and Skowronek argue that institutions have long been equated with homeostatic equilibria in political regimes. The enduring focus on institutions as "pillars of order in politics" frequently serves to exaggerate the fixity of political institutions, while eliding the inherent systemic fragilities, maladaptive responses, and "patterned anarchy" that actually comprise the core of much of political life. They conclude that the near-exclusive focus in much institutional analysis on explaining stability, order, and regularity "has obscured a good deal of what is characteristic about institutions in politics and what they have to teach us about political change." 28

Arguably also, with respect to the study of non-democracies, a neoinstitutionalist "iconography of order" may potentially be especially misleading, because institutions in authoritarian regimes commonly exist and operate at the discretion of rulers and their supporting elites. ${ }^{29}$ Whereas political institutions in democratic systems are generally interpreted to represent the equilibria of a game among open competitors that is stable, durable, and robust, in authoritarian political contexts, institutions are particularly susceptible to strategic manipulation by powerful elites. As Thomas Pepinsky points out, despite its use of sophisticated

27 Howard and Walters, "Explaining the Unexpected."
28 Orren and Skowronek, "Beyond the Iconography of Order."
29 Lagacé and Gandhi, "Authoritarian Institutions." 
qualitative and quantitative research designs, the existing "state-of-the-art" in empirical research on comparative authoritarianism has failed to demonstrate the causal effects of institutions on regime durability and resilience. ${ }^{30}$ Non-democratic regimes and the institutions that sustain them may persist over long periods of time, appearing to weather shocks and challenges, but may also - as was the case with the collapse of communist party-states across Eastern Europe and the Soviet Union - suddenly and quite unexpectedly melt away, despite the persistence of adequately functioning institutions. ${ }^{31}$ As Andrew Walder acknowledged in retrospect about the wave that brought down single-party-states beginning in 1989: "While today we can look back upon an inexorable cumulative crisis, a few years ago one could just as easily be struck by how little ... deeply rooted problems seemed to shake these stable and stagnant regimes ... [these] regimes [had] appeared [then] to be tougher, more resilient than other varieties of authoritarian rule - and in fact they were." 32 Ex post facto explanations of collapse that centered primarily on institutional factors, as Stathis Kalyvas argues, failed to differentiate between the relative impacts of institutional decline over the longer term, and the more immediate precipitants of institutional breakdown, and therefore ultimately could not provide a conclusive and robust answer to the question, "Why 1989 ?"33 Indeed, with the benefit of hindsight, we can now see that institutionally grounded arguments stressing systemic exhaustion can be interpreted as predicting both path-dependent self-perpetuation and sudden self-destruction in equal measure and, for that reason, lack real explanatory power. ${ }^{34}$

Not all researchers working within an institutionalist paradigm, of course, were contributing to quite such a static iconography. Those, especially, who were keenly involved in developing alternative modes of comparative-historical analysis had begun tackling questions about how institutions can and do change; thus moving away from older-style institutionalist exercises in "comparative statics," to generate something of a "burst of interest in institutional change." 35 New concepts such as "bounded innovation" and "gradual transformative change" - concepts aiming explicitly to conjoin structure with process as observed over time gained currency, ${ }^{36}$ especially in the study of advanced capitalism's

\footnotetext{
30 Pepinsky, “The Institutional Turn,” 633-635. ${ }^{31}$ Yurchak, Everything Was Forever.

32 Walder, "The Decline of Communist Power," 297-298; See also Dimitrov, "Understanding Communist Collapse and Resilience."

33 Kalyvas, "The Decay and Breakdown," 334.

34 Walder, "The Decline of Communist Power," 297.

35 Hacker, Pierson and Thelen, "Drift and Conversion," 203.

36 As, e.g., in Streeck and Thelen, Beyond Continuity.
} 
morphing economic institutions. To a degree, this newer, more evolutionary, strain in comparative-historical thinking also informed the recent spate of work analyzing, comparatively, the conditions and dynamics of durable authoritarianism. ${ }^{37}$ Little of this explicitly more process-oriented or "evolutionary" historical institutionalism, however, seems to have made its way into the literature on China. ${ }^{38}$

More widely noted, within the subfield of Chinese politics, has been some interesting work done lately by Elizabeth Perry, Sebastian Heilmann, and others, aimed at broadening our working concepts concerning adaptive authoritarianism. Rejecting excessively static or linear path-dependency perspectives on "resilience" in favor of an agencycentered definition of adaptability, Perry and Heilmann find that it is "the capacity of actors in a system to further resilience" through a process of continual adjustment that generally outweighs the importance of institutional mechanisms per se in securing regime persistence. In their reading, regime resilience depends on the ability and willingness of individual and collective actors either to innovate or to break from the "rules of the game," and to engage in "maximum tinkering" that may produce new discoveries and novel solutions to existing problems. Inasmuch as the CCP's "guerrilla policy style," as Perry and Heilmann identify and define it, is experimentalist and non-repetitive, they decline to characterize or classify it as an "informal institution." In their 2011 volume instead, through a series of retrospective studies, they trace this distinctive practice of policy generation permitting maximal flexibility as it was in operation from the Mao era forward across a broad range of policy areas, and down to the present day. ${ }^{39}$

Yet, despite the salutary theoretical efforts of scholars to leaven institutionalist linearity with considerations of "process" and "agency," the very concepts of adaptation and resilience, which have been imported into comparative governance studies from the ecological and engineering sciences, each carry core assumptions of their own that are problematic

${ }^{37}$ Levitsky and Way, "Not Just What, but When (and How)."

${ }^{38}$ For one very recent exception, however, see Ang, How China Escaped the Poverty Trap.

${ }^{39}$ Perry and Heilmann, eds., Mao's Invisible Hand. Even more recently, Martin Dimitrov and his collaborators have attempted a reprise of the institutionalist framework in synthesis with the continuous adjustment approach as it was articulated by Perry and Heilmann. Their research, which centers on adaptations within consolidated communist states in the realms of economy, ideology, party inclusiveness, and those institutions that promote official accountability, leads them to formulate a theory-straddling contention that the resilience of mature communist party-states "is a function of continuous adaptive institutional change," and ultimately to draw the spin-off conclusion that whereas the resilience of mature communist party-states "depends on the ability of [these] regimes to adapt, collapse is more likely when the regimes are no longer capable of implementing adaptive change." Dimitrov, ed., Why Communism Did Not Collapse, 3-4 (italics added), 16. 
in modeling political affairs. Assertions of the resilience or durability of a particular political system implicitly project assessments of that system's demonstrated capacity to weather previous crises and shocks into the future. Such rectilinear reasoning, however, is tenuous at best. As ecologist C. S. Holling - a leading critic of the concept of stable equilibria - explains, "what a complex system is doing seldom gives any indication of what it would do under changed conditions." ${ }^{40}$ And as Lewis and Steinmo have observed, whereas some colleagues in the social sciences continue reflexively to embrace an oversimplified version of "generalized Darwinism," modern evolutionary biologists are careful to avoid predicting future trends and outcomes in the systems they study. The most sophisticated contemporary advances in natural-world evolutionary theory recognize that random variations within complex systems can and very frequently do set development along totally new and unpredictable paths, not all of which contribute to or ultimately result in overall system survival. ${ }^{41}$ Or, as Anthony Giddens long ago perceptively tried to warn us, the concept of adaptation, when transposed from a natural world into a social context, is "irremediably amorphous": either applied so broadly that it is "vacuous," or supportive of "specious and logically deficient claim [s] to functionalist explanation." 42

Others too have cautioned that since complex non-linear systems are constantly evolving, lessons once learned in the past may no longer retain validity in the present, even amid circumstances that appear to have changed only slightly; and the nature of systems and systems equilibria also can and do change, often unpredictably. In other words, in both the natural world and the human one, behaviors and practices that appear merely adaptive may in fact, either incrementally or more rapidly, be shifting the mainstream of change, or even the system as a whole, in new and unanticipated directions. ${ }^{43}$ Then, too, accommodations in one realm of activity that appear positively adaptive in response to pressures or shifts in the short term may prove maladaptive over a longer time frame, generating path-dependent patterns or feedback loops that undermine the longer-term resilience of a system. ${ }^{44}$

In sum, current concepts of authoritarian resilience and adaptive change have, to be sure, proved useful in challenging the underlying but often implicit teleological assumptions of transitology. They have also offered us some new tools for analyzing how non-democracies may not

\footnotetext{
${ }^{40}$ Holling, Adaptive Environmental Assessment and Management.

${ }^{41}$ Lewis and Steinmo, "Taking Evolution Seriously in Political Science," 238-239.

42 Giddens, The Constitution of Society, 233-234.

${ }^{43}$ Nadasdy, "Adaptive Co-Management and the Gospel of Resilience."

${ }^{44}$ Pierson, Politics in Time.
} 
only survive but succeed over time. Nonetheless, researchers in our China studies subfield must confront the fact that more critical imagination is urgently called for if we are to move beyond "authoritarian resilience" and what remain its rather artificially narrowed conceptual frames. If genuinely non-linear paradigms and research questions and hypotheses not still heavily inflected by teleology and false dichotomy are ever to be achieved, then one of our most pressing tasks must be to capture better vantage points from which to survey the full field upon which the political action plays out. Our next step, that is, must be to seek new perspectives from which to apprehend the broader panorama of multivalent practices and processes that are all simultaneously present, exerting influences and energies, and needing to be traced out as contributors to the flow of China's swiftly ongoing political evolution.

Although, arguably, the literature we have been reviewing so far has constituted the mainstream of analysis, especially within the American academy and in the discipline of political science, not by any means all scholars in the China studies field in the West have followed precisely the sort of pathway from transitology to authoritarian resilience that we have sketched. Nor have all been as intent on privileging the study of institutions. Those especially who have been more deeply influenced by the Foucauldian turn in modern social theory have, in their own efforts to move away from the banal either/or choice between liberalism and authoritarianism, been offering us, instead, some interestingly different vantage points on these problems. Gary Sigley, for example, in his introduction to a special issue of Economy and Society on Chinese governmentalities, begins with the observation that "China's transition from 'plan' to 'market' has been accompanied by significant shifts in how the practice and objects of government are understood, calculated and acted upon." He speculates that we are witnessing the emergence of a "hybrid socialistneoliberal (or perhaps "neoleninist') form of political rationality that is at once authoritarian in a familiar political and technocratic sense yet, at the same time, seeks to govern certain subjects, but not all, through their own autonomy." ${ }^{45}$ In contrast to Foucault's original conception of governmentality, developed in the context of Western liberal societies, Sigley situates his discussion within a more comprehensive consideration of "non-Western governmentalities." He underscores the disparateness of the elements that can go into the making of such modern yet non-Western governing apparatuses, as well as the opportunism and historical conditionality of their formation. "There is no single hand, invisible or otherwise, projecting its will upon the population," he asserts, "on the

${ }^{45}$ Sigley, "Chinese Governmentalities," 489. 
contrary ... government is a much more decentred, ad hoc and contingent affair." ${ }^{46}$ Most revealingly in this vein, perhaps, the fascinating proliferation of novel "techniques of the self" and of other powerful forms of governmentality now emerging in China's rapidly restratifying, urbanizing, and globalizing society, has been well documented by contemporary China scholars, especially those working in the disciplines of sociology, anthropology, and cultural studies. ${ }^{47}$ And this too has alerted at least some students of politics to the imperative of expanding their analyses to accommodate those dimensions and practices of "governing" and of "governance" that lie beyond the reach of conventional political institutions and earlier twentieth-century models of "progress" toward political modernity.

For all these reasons, each one of the contributors to this volume may be read as striving, similarly, to move away from the dreary dichotomy of liberalism and authoritarianism to offer different vantage points on the problems of governing and being governed in China. We have shared a working orientation toward the understanding of governance today as full of countervailing pressures, moving in more than one direction at any one time, thus potentially full of paradox; as a hybrid or an amalgam, made up of rather widely differing purposes and praxes, not all of a piece; and as a complex of shifting forces, one most definitely with "no single hand" in control.

What we believe is required is an approach capable of accommodating, if not "patterned anarchy," then at the very least the mixed-effects multidirectionality observable within processes of political change; an approach attuned to recognizing the internal strains of criss-crossed and intersecting trends within political systems. We require a new metaphor, or frame for analysis capable of capturing incremental factors and processes, including those (both great and small, both institutional and otherwise) that can be regarded as contributing to form a "mainstream" of evolutionary change, along with those that may wander off into other channels, drawing strength away from the main, and complicating the interplay of political energies and forces. As elaborated further in the sections to come, striving for such a broader panorama - both of converging tributaries and of dead-ended or debilitating offshoot channels of change, such an interlaced modeling of the multiple directions of flow in patterns of

${ }^{46}$ Ibid.

${ }^{47}$ For readers not already entirely familiar with the concept, "techniques of the self" were defined by Foucault as: "those reflective and voluntary practices by which men not only set themselves rules of conduct, but seek to transform themselves, to change themselves in their singular being, and to make of their life an oeuvre that carries certain aesthetic values and meets certain stylistic criteria." Foucault, The Use of Pleasure, 10-11. 
political evolution over long periods of time - is the kind of approach we seek to assist in advancing in the research reported here.

\section{Reframing our Analyses: A Repertoire or a River?}

As noted here at the outset, therefore, our initial expectation for our 2012 conference was that, by displaying the illustrative variety of the authors' ongoing research and their findings, we would enable readers of this collection to perceive more vividly the very richness and expansiveness of the repertoire of diverse practices enmeshed in different dimensions of governing China today. Our starting point was, then, to acknowledge that whenever we look seriously at political life in China these days, we do find change and evolution continually taking place, but almost never change in just one direction. We believed that only by tacking back and forth - not just between different levels of institutions and groups of social actors, but also across the full panorama of quite different spheres of political and social encounter - would we begin to apprehend the criss-crossing pressures driving and reshaping patterns of governance, and of power, in China today. Our aim was to conduct a preliminary scan, as it were, of the operative range of governing practices open to careful study in the contemporary Chinese context.

This volume, accordingly, presents the findings of a rich array of up-to-date research investigations, consciously ordered and juxtaposed so as to highlight and illuminate the distinct types of governing practices they examine, and how these are currently at work in the contemporary Chinese polity. Our first three essays explore strategic practices at the level of national political leadership. Elizabeth Perry scrutinizes processes of manipulating political symbols and sentiments in hopes of generating authority and emotional support for the party's leadership. Looking at today's "public sentiment" offices and at new digital networks designed to access and assess popular mentalities, she explores the party-state's capacities to transform its vast propaganda apparatus from the forbidding echo chamber of the high-socialist past into more interactive platforms for sustaining mass engagement and persuasion. Sebastian Heilmann next traces distinctive practices of linkage and coordination which have been carried out over time at highest government levels in China, on a professed vital mission to rectify economic distortions and reconcile conflicting interests, while balancing and comprehensively steering the national economy and guiding its development. Vivienne Shue then explores contemporary, state-of-the-art practices of mapping, land use planning, and spatial redesign on a grand scale, as these are deployed now by an ever-more technocratically inclined Chinese political leadership seeking 
to manage the many unwieldy present-day social issues and obstacles it confronts partly through pictorial and cartographic exercises in envisioning the future. In these painstakingly mapped visions, we observe the totality of the Chinese nation-space now imagined as one of comprehensively ordered, thoroughly harmonized ultra-productive efficiency, with ecological sustainability and strict preservation guaranteed both for China's priceless natural resources and its prized cultural heritage.

In the following two essays, the spotlight shifts from governance practices at the highest levels of political leadership to sites part the way down the governance hierarchy, where state agents and citizens encounter one another more directly. In this realm - the realm of "people's government" in CCP parlance - we can better observe governing practices now deployed for the monitoring of popular dissatisfactions and the proper regulation of relations between agents of the state and an increasingly critical and demanding public. Here, Joel Andreas and Yige Dong reveal both interesting continuities and significant alterations over time in Chinese practices of "mass supervision," that longstanding CCP technique for eliciting public input and citizens' oversight of lower-level power holders within their single-party system. In this middling realm of governance also, Robert Weller considers and dissects state administrators' practices of overlooking, or "turning a blind eye" in the face of certain types of transgressive social behavior, episodes of popular noncompliance, even insubordination. Pretending not to notice can be a valuable option in the toolkits of mid-level officials tasked by their superiors to get many, many things done at once, especially when feigned ignorance of what is really going on amongst the people can work to harness extra popular energies to those tasks. Weller here invites us to look at some of the ways in which more ad hoc or informal political arrangements, encounters, and accommodations can prove both reasonably effective in achieving satisfactory social governance and even more enduring than outcomes attainable either through enforcement of formal rules or through repeated acts of resistance against those rules. He argues that "shared fictions" and "lies not intended to deceive" can serve as vital mechanisms for governing, especially in the quickly changing Chinese context, precisely because they are more amenable to improvisation, reinterpretation, and annulments as required.

Our next two essays are devoted to carefully unpacking some aspects of governance as it is currently practiced by agents of the "local state" in China's surging urban and urbanizing settings. Nothing has been more consequential for the trajectory of China's transformation over the last three decades than the calculated expansion of market and market-like 
relations and transactions throughout all aspects of human interaction economic, social, and governmental. And these two essays shed much fascinating light on the contemporary application of market-like exchange relationships to newly arising challenges in grassroots-level governance. Both essays focus on the hard-headed bargaining and deal-making techniques now commonly adopted by local-state actors to settle obstructive conflicts and disputes amid a vocal throng of newly empowered interested parties. As Ching Kwan Lee and Yong Hong Zhang make disturbingly clear in their study, the stakes are high for those who find themselves squatting in the path of urban progress. As protest actions by aggrieved citizens in China's cities have proliferated, local authorities have developed tactics for "buying order" or social stability, thereby turning social instability itself into a medium of exchange at the urban grassroots. Similarly, as Luigi Tomba details, for "rural" villagers anticipating the incorporation of their communities and properties into new urban spaces, the precise terms of exchange on which they will trade away their old collective entitlements in return for urban benefits are stubbornly negotiated. These often protracted tests of will embroil village elites, mid-level authority holders, and agents of the local state in ferocious contests for the best terms and conditions, and the sweetest deals. Through such local-state practices of buying and selling, the outcomes of the bargained settlements reached have varied significantly, yielding only greater fragmentation in what were already uneven patterns of grassroots governance practices.

In the final three essays, our contributors turn to consideration of contemporary Chinese practices of governing the individual, and to the widening exercise of "techniques of the self." Here, the emphasis is on a more subversive realm of governing practices - the making of new classes, the labeling of problematic social categories, and the setting of new individual standards of conduct and quality as measures of personal attainment. Jean-Louis Rocca first dissects the intertwined and crosscutting processes entailed in the making of China's new middle classes. Idealizing, even lionizing, these classes and their habits to celebrate and represent modernity's social "winners" has been and remains a contested process in itself, as he reveals, but one with profound implications for how the contemporary "Chinese urban" is now designed and managed, as well as for how a contemporary "Chinese-style urbanity" is being imagined and enacted, before both domestic and global audiences. Patricia Thornton examines the party-state's multi-stranded governing strategies for simultaneously patronizing and policing the new urban underclass, by conjoining the goals of party-building, public service, and social welfare management at the grassroots in China's fast-growing cities. She 
finds that, alongside new discourses both of salutary self-help and of solicitous charitable assistance to those at the bottom of the social hierarchy, the party now combines "party-building" and "mass work" techniques inherited from the past with newer modes of recruiting, surveiling, and subduing members of the urban poor and the "at-risk" populations, in its quest to guarantee social harmony and stability in urban neighborhoods.

In our final study of haunting - a disciplining of the modern self that internalizes within the person a determined, ever-restless "will to improve" - Christian Göbel and Thomas Heberer delve most deeply of all into the ways by which new "techniques of the self" are being applied to the governing of China's governors. Their analysis explores how the imperative pressures brought to bear on party-state officials prompt them to seek ways of raising their game and of improving their performance, particularly through acts of demonstrable, practical problemsolving, policy innovation. They show how this micro-technique of power, although it is applied at the level of the individual official, can be multiplied to produce far-reaching results in redistributing power and responsibility across the entire governing apparatus. If Chinese mid- and low-level officials are increasingly "haunted" by a felt need to improve themselves, as Göbel and Heberer argue, will society and economy be better governed? (Such is the positive, calculated hope of the leadership in Beijing, of course.) Or will other social and economic actors, beyond the bureaucracy, not be swept up and "haunted" too, in the pulsating imperative to keep up? Read together, these three final essays map out several intriguingly fresh territories in Chinese politics and society where what it now means to govern, and to be governed, are still to be explored.

Nurturing self-disciplining state officials possessed of an obsessional "will to improve"; idealizing and celebrating the socio-economy's new classes of "winners"; patronizing and policing its potentially troublesome "losers"; mixing threats with monetary inducements to strike hard political bargains at local levels; disregarding legal violations and overlooking certain political transgressions when convenient; renewing and updating routinized systems for the public oversight of officials; emphatically envisioning glowing futures for the nation, mediated through the magic of super-sophisticated high-tech tools and computer projections, while holding out a dream of sublime balance and bounty; determinedly steering the national economy "rationally," comprehensively and from the top; and assiduously manipulating public sentiment through the repackaging of key historical and cultural symbols - these are some of the most salient and intriguing practices of governing in China today that our contributors have uncovered and chosen to highlight. But is a "repertoire" the most 
appropriate frame or metaphor to use, we must now pause to reconsider, in characterizing such an interesting tangle of techniques?

Two important observations can be made about the practices our contributors have elucidated here. First, and in all cases, the practices we have drawn attention to in this volume do not conform to fixed scripts; they are not static, but are in themselves continually undergoing renewal, revision, and reform. Such governing practices as these are, in themselves, and as a collection or constellation of governing techniques, forever fluid; continuously "in the making." Second, these practices are never performed singly; they overlap each other in time, inhabiting different spaces or dimensions, so to speak, of the larger overall process of governing, intersecting with one another at intervals, but with no one set of practices ever dominating all the action on the political stage. The political stage itself, in fact, does not seem very much to resemble the single platform, artfully set and suitably illuminated, situated at the front of a theater designed to hold the spellbound gaze of an audience. The stage on which the performance of governing proceeds appears more akin to that of a carnival or circus with multiple rings, stalls, and tents all simultaneously offering separate juggling or gymnastic acts, trained animal tricks, popular attractions, games and amusements, some of which the circusgoer is intended only to watch and applaud, but others where the public can join in and try, perhaps, to win a prize.

These two important features of the governance practices explored here - their kinetic fluidity and the simultaneity of their performance are perhaps not, after all, best captured conceptually as choices made from a pre-set menu or from a pre-rehearsed theatrical repertoire. It was of course Charles Tilly who, most recently and influentially all across the social sciences, deployed the notion of a "repertoire" in his towering studies of collective action. Adapting, as we set out to do, this metaphor of a repertoire to express the availability of a range of political options, from the study of protest to the study of issues and tactics in governing can also, we do still believe, be useful as an initial orientation to analysis. But if we are to be faithful to Tilly's concept, and avoid stretching it unduly when applying it in the contemporary Chinese context, then we are bound to be attentive to the points where it is discovered to be ill-fitting.

Tilly used the term "repertoire" to describe "a limited set of routines that are learned, shared and acted out through a relatively deliberate process of choice. Repertoires are learned cultural creations, but they do not descend from abstract philosophy or take shape as a result of political propaganda; they emerge from struggle." Rooted in the everyday lived experience of a population, repertoires arise from the practices of "daily social life, existing social relations, shared memories and the logistics of social settings." 
By the same token, individuals "experiment constantly with new forms in the search for tactical advantage, but do so in small ways, at the edge of well-established actions." Thus, Tilly understood the "repertoire" as channeling and constraining people's actions along certain well-established pathways, "even when in principle some unfamiliar form of action would serve their interests much better." ${ }^{\text {" }}$ As on Tilly's conception, our contributors do clearly understand contemporary Chinese repertoires of governing practices as, to a degree, both channeling and constraining the work of party-state agents through familiarly patterned sequences and along certain well-worn tracks, to be sure. But the emphasis in these studies is far more, we would have to say, on reinvention; on disrupting prior sequences, departing from previous practices, and deliberately creating new conduits of political interchange if, despite their unfamiliarity, these can be crafted, by governors and governed alike, to "serve their interests much better." And here it is, or so it seems to us now, that the conceptual framework of the repertoire reaches certain limits, and does not fit the dynamically unfolding facts on the ground in China quite as well as we had foreseen.

Is there a more fluid metaphor, a better-fitting heuristic to be conjured for our conceptual purposes and tasks, then? Heeding the injunction of Lewis and Steinmo ${ }^{49}$ about "taking evolution seriously in political science," the findings of our contributors have stimulated us to turn our attention to some of the revisionist theorizing now taking shape in the fields of evolutionary ecology, including research in macro-evolutionary processes. We have been curious to consider, in particular, some of the very latest and very inspiring work being done by paleo-anthropologists investigating the evolutionary histories of primates, including early hominins such as Australopithecus, and the emergence of the genus Homo. Propelled by advances in DNA analysis, and by some extraordinary fossil finds made in recent years over different parts of the globe, these sciences have been going through an especially rich period of theoretical questioning and rethinking. With working assumptions rooted in the Darwinian model of evolution, scientists in these fields once sketched their images of evolutionary change (including primate evolution) in a straight, linear, ever upwardly ascending design; a convention that was later replaced by a conception which came to be represented in the form of a branching tree, and then a bush. But the branches (differing species) on such trees and bushes, still familiar to every school child just a generation ago, were imagined as discrete ones, growing off and away from each other, never to interconnect again in space or time.

48 Tilly, Popular Contention in Great Britain, 1758-1834, 42; Tilly, "How to Detect, Describe and Explain Repertoires of Contention," 7.

${ }^{49}$ Lewis and Steinmo, "Taking Evolution Seriously in Political Science." 
With the lately mounting genetic and fossil evidence of early hominin population flows and intersections (even inter-breeding), however, many today have concluded that "It is now time to replace" the representation of a tree "with that of an interwoven plexus of genetic lineages that branch out and fuse once again with the passage of time." ${ }^{50}$ A new impetus has emerged lately in evolutionary science circles in favor of substituting a more liquid, watery image - and specifically, that of a "braided stream" - for the familiar, but stiff and twiggy tree. The "braided stream" looks now to be a leading candidate for representing some of these empirical researchers' fresh understandings of the processes they have uncovered through empirical research. ${ }^{51}$

It is worth noting that this concept of a "braided stream" was not invented by the paleo-anthropologists, but rather borrowed by them from the science of physical geography, as a metaphor to better capture the overall patterns of flow and change that they have been observing and seeking to describe. Braided rivers frequently form when glacial ice melts (Figure I.1). Water moves away from the source in fast-flowing streams and rivers, sometimes (depending on the nature of the underlying substrate) transporting great quantities of sediment and larger debris. If the sediment load is very large in relation to the velocity of the stream, coarser material may begin blocking the stream, diverting it and forcing it, often repeatedly, to change course.

Such rivers consist of multiple, smaller channels that divide and recombine, forming an intertwining pattern resembling a braid. A dynamic and fluid model like this may also be appropriately employed to express overall patterns encountered in other evolutionary processes, including political evolutions, such as those captured in the work of our contributors. A dynamic and fluid model, postulating an ornate tracery of interlacing flows, traveling at differing speeds over uneven spaces and across time could, we think, be fruitfully adapted as a guide to future research in comparative politics as well; as a supplement to some of our more familiar linear (tree-like) and performative (repertoire-like) heuristics.

${ }^{50}$ Non-scientists, see Finlayson, "Viewpoint." For a more technical report on some of the science leading up to this change in view, see Hawks and Cochran, "Dynamics of Adaptive Introgression."

${ }^{51}$ For a discussion of the concept aimed at a public policy audience, see Chatteriee, "The River of Life." The stunning and much publicized 2015 report on fossil finds at the Rising Star cave site in South Africa, which documented a previously unknown extinct species of the genus Homo, has only added greater persuasive power to such calls for a more riverine model of evolutionary change over extremely long periods of time. The full technical report on these finds can be found at Berger et al., "Homo naledi." One non-specialist account is Shreeve, "This Face Changes the Human Story." On the virtues of more woody and more watery metaphors, see Van Arsdale, "Moving beyond Trees." 


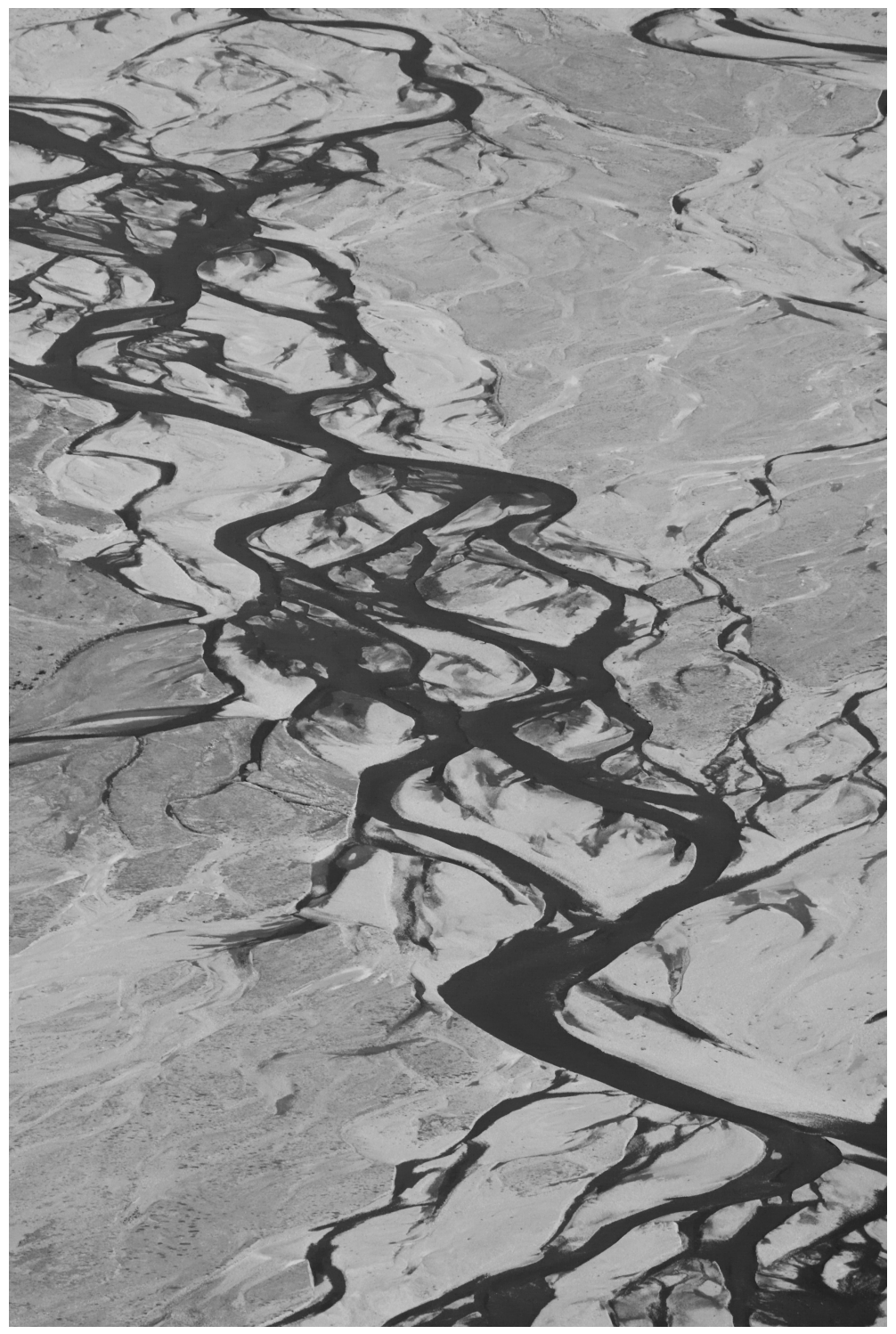

Figure I.1 Meandering Hopkins River, South Island, New Zealand Credit: Danita Delimont. 
Each of the essays in this volume explores a different dimension of governing as it is being practiced in China today; an analytically distinguishable tributary in the tangled currents of political change. Each is presented below on its own terms and in its own scholarly voice. There has been no attempt to impose a unified view or judgment in the studies collected here. When read together, however, we believe these essays can serve to point our field on to some new conceptual starting points, and fresh research directions. While none of the scholars writing here would ever suggest that institutions, as such, either can or should be overlooked or neglected when studying political and social change, their essays have focused less on governing institutions per se, and more on processes animating, supplementing (or sidestepping) those institutions. As a collection, therefore, they do highlight the harvest to be gleaned by a deliberate broadening of our empirical and analytical concerns beyond the familiar boundaries of a "system reform" approach to our studies, to discern what can be learned as well from explicit observations of governing in practice, and the consequences of those practices for the overall patterning of power processes.

Read and considered together, the essays here also make it apparent that processes of governing and being governed are enacted not as a single, allabsorbing theatrical repertoire. They may be better approached as a circus, staged in different rings and under many tents at once, with performers and audiences intermingling and band music and crowd noises carrying from one space to the next. Under such performing conditions, improvisation can count for as much, or even more, than pre-rehearsals. The model these collected essays suggest, for approaching the study of governance in the Chinese context today therefore, is that of a work (always) "in progress": a work in perpetual if uneven flow, sometimes interrupted, winding and backtracking around obstructions, sometimes even splitting or parting ways to head off in divergent directions from a single juncture. This would be a model of evolutionary change, as it is now being theorized in some of the biological sciences, rather than a model of either linear transition or of orbiting involution and reprise.

To govern China now, these essays suggest, is to meander: a multistranded process which privileges nimbleness, mutability, and an openness to institutional invention and procedural change, both proactive and reactive. Such protean qualities as these are not ones most political scientists associate either with the functioning of routinized, elite-managed authoritarian political systems or with the prevailing political rhythms that characterize institutionalized, electoral and rule-of-law based democratic systems. Yet they seem to us to capture well that condition of unceasing restlessness so characteristic both of those striving to govern, and of those being governed, in China today. 


\section{References}

Ang, Yuen Yuen. How China Escaped the Poverty Trap. Ithaca, NY: Cornell University Press, 2016.

Armitage, Derek, Berkes, Fikret, and Doubleday, Nancy, eds. Adaptive Comanagement: Collaboration, Learning and Multi-level Governance. Vancouver: University of British Columbia Press, 2007.

Art, David. "What Do We Know about Authoritarianism after Ten Years?," Comparative Politics: (April) 2012, 351-373.

Berger, Lee R., Hawks, John, de Ruiter, Darryl J., Churchill, Steven E. et al. "Homo naledi, a New Species of the Genus Homo, from the Dinaledi Chamber, South Africa," eLife 2015, at elifesciences.org/content/4/e09560.

Blaydes, Lisa. Elections and Distributive Politics in Mubarak's Egypt. Cambridge: Cambridge University Press, 2011.

Bogaards, Matthijs. "How to Classify Hybrid Regimes? Defective Democracy and Electoral Authoritarianism," Democratization, 16, 2: 2009, 399-423.

Brownlee, Jason. Authoritarianism in an Age of Democratization. Cambridge: Cambridge University Press, 2007.

Bunce, Valerie. Subversive Institutions: The Design and the Destruction of Socialism and the State. New York: Cambridge University Press, 1999.

Cabestan, Jean-Pierre. "Is China Moving Towards 'Enlightened' but Plutocratic Authoritarianism?," China Perspectives, 55 (September - October): 2004, at chinaperspectives.revues.org/412.

Carothers, Thomas. "The End of the Transitions Paradigm," Fournal of Democracy, 13, 1: 2002, 5-21.

Chatterjee, Sankar. "The River of Life: A Genetic Perspective on Macroevolution," Forum on Public Policy, 2009, at forumonpublicpolicy .com/summer09/archivesummer09/chatterjee.pdf.

Dickson, Bruce. Red Capitalists in China: The Party, Private Entrepreneurs and Prospects for Political Change. Cambridge: Cambridge University Press, 2003.

Dimitrov, Martin K. "Understanding Communist Collapse and Resilience," in Dimitrov, ed., Why Communism Did Not Collapse, 3-39.

Dimitrov, Martin K., ed. Why Communism Did Not Collapse: Understanding Authoritarian Regime Resilience in Asia and Europe. Cambridge: Cambridge University Press, 2013.

Dittmer, Lowell. "Three Visions of Chinese Political Reform," Fournal of Asian and African Studies, 38, 4-5: 2003, 347-376.

Dodd, Lawrence C. and Jilson, Calvin, eds. The Dynamics of American Politics: Approaches and Interpretations. Armonk, NY: Westview Press, 1994.

Edin, Maria. "State Capacity and Local Agent Control in China: CCP Cadre Management from a Township Perspective," China Quarterly, 173: 2003, $35-52$.

Finlayson, Clive. "Viewpoint: From Tree to Braid." BBC Science and Environment, December 31, 2013, at www.bbc.co.uk/news/science-environment-25559172.

Foucault, Michel. The Use of Pleasure. The History of Sexuality: Volume Two. Trans. R. Hurley. Harmondsworth: Penguin (1992) [1984].

Gandhi, Jennifer. Political Institutions under Dictatorship. Cambridge: Cambridge University Press, 2010. 
Giddens, Anthony. The Constitution of Society: Outline of the Theory of Structuration. Cambridge: Polity Press, 1984.

Hacker, Jacob S., Pierson, Paul, and Thelen, Kathleen. "Drift and Conversion: Hidden Faces of Institutional Change," in Mahoney and Thelen, eds., Advances in Comparative-Historical Analysis, 180-208.

Hawks, John and Cochran, Gregory. "Dynamics of Adaptive Introgression from Archaic to Modern Humans," PaleoAnthropology: 2006, 101-115, at webpages. icav.up.pt/ptdc/CVT/105223/2008/References\%20for\%20BigBos\%20proposal \%20[PTDC-CVT-105223-2008]/PDF\%20files\%20of\%20references_ $\max 30 \% 20[\mathrm{BigBos}] /$ Hawks\%202006_Review\%20on\%20human\%20introgres sion.pdf.

Heberer, Thomas and Schubert, Gunter. "Political Reform and Regime Legitimacy in Contemporary China," ASIEN, 99: 2006, 9-28.

Heilmann, Sebastian and Perry, Elizabeth J., eds. Mao's Invisible Hand: The Political Foundations of Adaptive Governance in China. Cambridge, MA: Harvard University Asia Center, 2011.

Holling, C. S. Adaptive Environmental Assessment and Management. London: John Wiley and Sons, 1978.

Howard, Marc Morjé and Walters, Meir R. "Explaining the Unexpected: Political Science and the Surprises of 1989 and 2011," Perspectives on Politics 12, 2: (June) 2014, 394-408.

Jones, Calvert W. "Seeing like an Autocrat: Liberal Social Engineering in an Illiberal State," Perspectives on Politics, 13, 1: (March) 2015, 26.

Jowitt, Ken. New World Disorder: The Leninist Extinction. Berkeley: University of California Press, 1992.

Kalyvas, Stathis N. "The Decay and Breakdown of Communist One-Party Systems," Annual Review of Political Science 2: 1999, 323-343.

Lagacé, Clara Boulianne and Gandhi, Jennifer. "Authoritarian Institutions," in Dimitrov, ed., Why Communism Did Not Collapse, 278-291.

Landry, Pierre. Decentralized Authoritarianism in China: The Communist Party's Control of Local Elites in the Post-Mao Era. Cambridge and New York: Cambridge University Press, 2008.

Levitsky, Steven and Way, Lucan A. Competitive Authoritarianism: Hybrid Regimes after the Cold War. Cambridge: Cambridge University Press, 2010.

Levitsky, Steven and Way, Lucan A. "Not Just What, but When (and How): Comparative-Historical Approaches to Authoritarian Durability," in Mahoney and Thelen, eds., Advances in Comparative-Historical Analysis, 97-120.

Lewis, John and Xue Litai. "Social Change and Political Reform in China: Meeting the Challenge of Success," China Quarterly, 176: 2003, 926-942.

Lewis, Orion and Steinmo, Sven. "Taking Evolution Seriously in Political Science," Theory in Biosciences, 129: 2010, 235-245.

Li, Cheng. "The End of the CCP's Resilient Authoritarianism? A Tripartite Assessment of Shifting Power in China," China Quarterly, 211: 2012, 595-623.

Magaloni, Beatriz. Voting for Autocracy: Hegemonic Party Survival and its Demise in Mexico. New York, Cambridge: Cambridge University Press, 2008.

Mahoney, James and Thelen, Kathleen, eds. Advances in Comparative-Historical Analysis. Cambridge: Cambridge University Press, 2015. 
Merkel, Wolfgang. "Embedded and Defective Democracies," Democratization, 11, 5: 2004, 33-58.

Nadasdy, Paul. "Adaptive Co-management and the Gospel of Resilience," in Armitage, Berkes, and Doubleday, eds., Adaptive Co-management, 208-227.

Nathan, Andrew J. "Authoritarian Impermanence," Fournal of Democracy, 20, 3 : 2009, 37-40.

Nathan, Andrew J. "Authoritarian Resilience," fournal of Democracy, 14, 1: 2003, 6-17.

Orren, Karen and Skowronek, Steven. "Beyond the Iconography of Order: Notes for a 'New Institutionalism'," in Dodd and Jilson, eds., The Dynamics of American Politics, 311-330.

Pei, Minxin. "Is CCP Rule Fragile or Resilient?" Fournal of Democracy, 23, 1: 2012, 27-41.

Pepinsky, Thomas. "The Institutional Turn in Comparative Authoritarianism," British fournal of Political Science, 44: 2013, 631-653.

Pieke, Frank N. The Good Communist: Elite Training and State Building in Today's China. Cambridge: Cambridge University Press, 2009.

Pierson, Paul. Politics in Time: History, Institutions, and Social Analysis. Princeton: Princeton University Press, 2004.

Schedler, Andreas, ed. Electoral Authoritarianism: The Dynamics of Unfree Competition. Colorado: Lynn Rienner, 2006.

Schubert, Gunter. "Reforming Authoritarianism in Contemporary China: Reflections on Pan Wei's Consultative Rule of Law Regime," ASIEN, 94: 2005, 7-24.

Shambaugh, David. China's Communist Party: Atrophy and Adaptation. Berkeley: University of California Press, 2008.

Shirk, Susan L. China: Fragile Superpower. Oxford: Oxford University Press, 2008.

Shreeve, Jamie. "This Face Changes the Human Story. But How?," National Geographic, September 10, 2015, at http://news.nationalgeographic.com/2015/ 09/150910-human-evolution-change/.

Snyder, Richard. "Beyond Electoral Authoritarianism: The Spectrum of Nondemocratic Regimes," in Schedler, ed., Electoral Authoritarianism, 219-232.

Streeck, Wolfgang and Thelen, Kathleen, eds. Beyond Continuity: Institutional Change in Advanced Economies. Oxford: Oxford University Press, 2005.

Sun Liping (孙立平). (“The 'Phantom of Instability' and the Vicious Cycle of Stability Maintenance”). ““不稳定幻像”与维稳怪圈,”人民论坛, 7:2010,23-4.

Tilly, Charles. "How to Detect, Describe and Explain Repertoires of Contention," Working Paper No. 150, Center for Studies of Social Change, The New School for Social Research, New York, 1992.

Tilly, Charles. Popular Contention in Great Britain, 1758-1834. Cambridge, MA: Harvard University Press, 1995.

Tsai, Kellee. "Adaptive Informal Institutions and Endogenous Institutional Change in China," World Politics, 59: 2006, 116-141.

Tsai, Kellee. Capitalism without Democracy: The Private Sector in Contemporary China. Ithaca, NY: Cornell University Press, 2007. 
Tsai, Lily L. Accountability without Democracy: Solidary Groups and Public Goods Provision in Rural China. New York: Cambridge University Press, 2007.

Tsai, Wen-Hsuan and Dean, Nicola. "The CCP's Learning System: Thought Unification and Regime Adaptation," China fournal, 69: 2013, 87-107.

Van Arsdale, Adam. "Moving beyond Trees: Metaphors for Evolution," The Pleistocene Scene - A.P. Van Arsdale Blog, September 10, 2015, at blogs .wellesley.edu/vanarsdale/2015/09/29/fossils/moving-beyond-trees-metaphors -for-evolution/.

Walder, Andrew G. "The Decline of Communist Power: Elements of a Theory of Institutional Change," Theory and Society, 23, 2: 1994, 297-323.

Yang, Dali L., Remaking the Chinese Leviathan: Market Transition and the Politics of Governance in China. Stanford: Stanford University Press, 2004.

Yu Jianrong (于建嵘). (“From Rigid Stability to Resilient Stability: An Analytical Framework for China's Social Order”). “从刚性稳定到韧性稳定 - 关于中国社 会秩序的一个分析框架,”学习与探索, 184: 2009, 113-118.

Yu Jianrong (于建嵘). (“The Present Predicament of Stability Maintenance Pressure and the Way Forward”). “当前压力维稳的困境与出路,”探索与争 鸣, 9: 2012, 6.

Yurchak, Alexei. Everything Was Forever, Until It Was No More: The Last Soviet Generation. Princeton: Princeton University Press, 2006.

Zheng, Yongnian. Will China Become Democratic? Elite, Class and Regime Transition. Singapore: Eastern Universities Press, 2004. 